\title{
The Importance of Employee Satisfaction: A Case Study of a Transportation and Logistics Service Company
}

\author{
ENEJA SILA \\ University of Primorska, Slovenia \\ enejasila@gmail.com \\ KLEMEN ŠIROK \\ University of Primorska, Slovenia \\ klemen.sirok@fm-kp.si
}

This paper draws attention to the importance of employee satisfaction in the transportation and logistics service industry. For research purposes, Spector's job satisfaction survey was used, which observes nine facets of job satisfaction, helping us to outline the viable measures that could improve employee satisfaction in the selected company. The research indicates that the employees were satisfied with their supervision, co-workers and the nature of work. Indifference was expressed with respect to payment, rewards, benefits, working conditions and communication. Dissatisfaction was only identified in the field of promotion opportunities. The identified facets that trigger different feelings of satisfaction also serve to explain the possible consequences fort the effectiveness of the selected transportation and logistics service company and the whole industry sector as such.

Key words: employee satisfaction, job satisfaction survey, behaviour, logistics, lorry drivers, performance https://doi.org/10.26493/1854-4231.13.111-136

\section{Introduction}

To successfully operate, companies need satisfied employees because employee satisfaction can lead to the commitment, conscientiousness and honesty of an employee, which in turn relate to their job performance (Gruban 2010, 4). In achieving employee satisfaction, the work environment plays a crucial role since it affects the life of individuals, their behaviour, perception and performance (Harter, Schmidt, and Keyes 2002, 1).

According to Surugiu and Surugiu $(2015,132)$, changes in the labour market's emerging due to globalisation have significantly affected companies' operations and their competitiveness. For com- 
panies operating in the transportation and logistics service industry, the situation is not considerably different (Kherbash and Mocan $2015,44)$. In the Slovenian transportation and logistics service industry, the strong pressure of competitors from Eastern European countries was recently detected, mostly from Hungary and Slovakia, as well as Bulgaria, Turkey and Romania. With incoming offers of cheaper services from foreign transportation and logistics service companies, the situation facing Slovenian road hauliers has become significantly tougher (Pečar 2014, 44). In addition to companies, workers themselves experience the impact of such critical conditions. In trying to provide quality services within the shortest possible time and at affordable prices, management structures have become subjected to increased pressures to perform and as a consequence often neglect the importance of all worker groups. According to Karimi et al. $(2017)$ and Godec $(2013,11)$ different physical and mental workloads can consequently trigger stress, frustration or dissatisfaction in employees and can affect job performance (Judge et al. 2001, 376). Additional stress and work-related challenges impact unskilled and low-skilled workers to a greater extent as they seek to cope with the required communication skills and timeliness (Svetličič 2008, 23).

In this paper, we study factors of employee satisfaction in a transportation and logistics services company. Unlike in other sectors such as healthcare (Faragher, Cass, and Cooper 2005), education (Skaalvik and Skaalvik 2017), public administration (Peklar and Boštjančič 2014), the police (Bobnar 2014), the army (Dimec et al. 2008) and tourism (Gorenak 2011), as well across industries (Lisjak 2011; Zidar 2009), research into employee satisfaction is underdeveloped in the field of transportation and logistics. The organisational behaviour research in the transportation and logistics service industry is more focused on studying the health issues and occupational risk factors of professional drivers (De Croon et al. 2002; Bovenzi et al. 2006). According to Pavlin (2014), more than 6,00o road hauliers and 17,000 commercial vehicles are registered in Slovenia, indicating the prevalence of the transportation and logistics service industry and, in addition, supporting the relevance of our research. Due to the diversification of the transportation and logistics service industry and the increasing need for effective employees, it is necessary to address the issues of transportation and logistics service workers' satisfaction and the positive effects of employee satisfaction.

The effects of satisfied employees can be seen in satisfied customers and higher service demand (Anderson, Fornell, and Lehmann 
1994, 53; Antonaki and Trivellas 2014, 356; Söderlund 2017, 1-2). In return, these contribute to the spread of goodwill, the positive economic returns of high quality service (Jha et al. 2017, 283; Hong et al. 2013, 239) and, of course, to a small number of work-related accidents, penalties for road traffic offences, mistakes etc. (Bener et al. $2017,22)$ which, after all, is the goal of companies engaged in road transportation activities. By examining professional drivers' work relationships, it was found that individuals can exert an important impact on a company's performance and that, by monitoring employee satisfaction, companies can obtain important information for handling absenteeism and employee turnover, which are major issues for many transportation and logistics companies (McElroy et al. 1993, 1-2; De Croon et al. 2002, 357).

Transportation and logistics service workers encounter many challenges that affect their job satisfaction. Especially affected are professional groups such as lorry drivers and truck dispatchers due to the specific working conditions, the nature of the work (Gorenak 2011, 26) and the work environment (Sendall et al. 2016, 32). The specifics of this 24-hour economy reflect in the flexible working time, increasing mechanisation, automation, and application of information and communication technology (De Croon et al. 2002, 357). Professional drivers are required to sit for long periods and maintain a single posture, while on the other hand, the loading and unloading of goods can also require significant physical effort. Because driving requires more concentration, attention and wakefulness (De Croon et al. 2002, 357) and because work is often performed at inconvenient working hours, it can be considered as physically demanding work.

To all this, we can add the reduced possibility of hygienic care, unhealthy eating habits and, lifestyle as such, as well as the lack of recreational opportunities (Greenfield et al. 2016). All this can affect both the psychological and physical health of drivers, which is particularly important for the safety of all traffic participants and freight, as well as the costs incurred due to accidents. In addition, we should also take into consideration the amount of stress and problems caused by (poor) foreign language proficiency, the (challenging) adaptation to life in a foreign country, inadequate job training, misunderstanding of administrative matters etc.

In this paper, we first present the theoretical framework by identifying the challenges and work specifics affecting employee satisfaction in the transportation industry as well as the dimensions of the job satisfaction concept. We also provide a detailed description of 
the job satisfaction survey (henceforth referred to as the Jss), used as a tool for measuring employee satisfaction in our research. After presenting the empirical analysis within the selected Slovenian transportation and logistics service company, we outline the recommendations for companies in the transportation industry.

\section{Theoretical Framework}

A variety of definitions of employee satisfaction can be found; however, they all describe job satisfaction as a result or a form of behaviour that an individual brings to the workplace (Weiss 2002, 174; Cooper and Locke 2000, 166; Levi 2006, 288; Smith, Kendall, and Hulin 1969). It is often described as a multidimensional psychological response to one's job, referring to internal cognitive (perception) and affective (emotional) states accessible by means of verbal or other behavioural and emotional responses (Hulin and Judge 2003, 256; Atefi et al. 2015, 2; Hayes, Douglas, and Bonner 2015, 5). For our research purpose, Spector's $(1997,2)$ definition is also relevant. The author identifies job satisfaction as 'how people feel about their jobs and different facets of their jobs.' In particular, he stresses the link between negative and positive emotions that affect employees' behaviour and performance, which in turn affect organisational results.

Measuring employee satisfaction is particularly relevant from the perspective of a company's performance (Meneghel et al. 2016, 1112). Satisfaction increases the sense of belonging to the company (Gil, Llorens, and Torrente 2015, 100), making employees perform more conscientiously and with greater commitment (Babalola 2016, 935-937; Pham and Pham 2016, 1445), which enables the company's further growth, development and competitiveness (Huang, Huang, and Tzeng 2016). Harter, Schmid and Hayes $(2002,268)$ also believe that job satisfaction relates to higher efficiency, productivity and lower absenteeism. This also affects individuals' willingness to acquire new skills (Dubey and Gunasekaran 2015), make more small improvement suggestions and innovation propositions, and increase their dedication to long-term company success (Zupan 1999, 5). The importance of managers in ensuring employees' engagement level, commitment, and satisfaction with their company (Peng et al. 2016, 2; Harter, Schmidt, and Hayes 2002, 269) can be shown by considering job characteristics (Hackman and Oldham 1974) and an employee's personality (Judge, Bono, and Locke 2000). At the same time, research also shows a higher correlation between job satisfaction and job performance in the case of more demanding and complex 
jobs (Judge and Saari 2004, 398; Korschun, Bhattacharya, and Swain 2014, 6-7; Blickle et al. 2013, 2).

Companies that do not promote employee satisfaction can on the other hand encounter deviant work behaviour manifested as delays, absenteeism or turnover (Spector 1997, 58; Levi 2006, 301) as well as counterproductive behaviour-behaviour that damages the company and appears in the form of corruption, sabotage, extortion, theft, fraud or violence (Levi 2006, 305). Judge and Saari $(2004,399)$ also point out a possible increase in abuse of alcohol, drugs and stimulants, along with conflicts and strikes. In addition, employees who experience feelings of dissatisfaction are less prone to invest additional efforts. They tend to avoid voluntary extra work, fail to achieve performance standards or carry out their work on time, complain about trivial things, don't want to follow instructions and quickly accuse others of wrongdoing (Keenan 1996, 6; Špitlar 2009, 34). These behavioural patterns can lead to high long-term costs, causing a lack of personnel, delays, errors and, in particular, work-related errors.

Different theoreticians examine a variety of job facets which represent stimulus for awakening different emotions, both positive and negative (Judge and Saari 2004, 395-396; Robbins and Judge 2015; Huczynski and Buchanan 2013; Schermerhorn et al. 2012). Since we are applying Spector's (1997) model, we present the following facets causing job-related (dis)satisfaction: pay, fringe benefits, supervision, contingent rewards, operating procedures, communication, and the nature of work, promotion, and co-workers.

\section{Methodology}

Spector's job satisfaction survey (henceforth referred to as the Jss), measures nine facets of job satisfaction and was developed in 1985 specifically for public and non-profit sector organisations (Spector $1985,693-705)$. The questionnaire itself was created based on job rearrangement and job enrichment, which is today known as Hackman and Oldham's job characteristic model (Hackman and Oldham 1974, 1-10) that explains the link between critical psychological states, core job dimensions, and personal and work outcomes. The jss can be used in various settings because it is understandable, easy to administer and of suitable length. These are also the main reasons why it was chosen for our research.

Our research aims at examining the level of job satisfaction and determining how the facets of satisfaction influence employee productivity and behaviour, as well as how to improve employees' satisfaction at work. In order to obtain an in-depth understanding within 
a single company under observation, a mixed-methods research approach was applied. According to Gravetter and Forzano $(2015,590)$ as well as Vogt, Gardner and Haeffele (2012), this research design can also be labelled a case study. First, an anonymous survey was used based on the Jss questionnaire. Subsequently, additional information was obtained through semi-structured interviews allowing both, a more descriptive as well as an exploratory account of the case based on inductive reasoning (Bengtsson 2016, 9-10), whereby interview questions were developed based on the survey results following the sequential mixed methods design (Lobe 2006).

We selected the company based on the demonstrated interests of company owners and the data availability. The data collection took place between 19th September and 2nd October 2014. The survey questionnaires were partially forwarded to the company's top management, who then distributed them among the employees. One part of the questionnaires was distributed by the researchers. Most employees completed the questionnaire in the company's rest area on the day when they returned from abroad. The completion of questionnaires took approximately 15 minutes. Surveys were returned in unmarked envelopes, providing respondent anonymity.

The survey was carried out on the population of employees in the selected company. At the time of the research, the company employed 18 workers, excluding the company owners. In order to obtain unbiased results, we excluded the business executives (owners); in our case, the procurator (founder), the managing director (son of the founder) and the head of the accounting department (the manager's wife), because employees reflect a different affiliation and involvement in the working process compared to company owners and executives. The observed population thus consists of 15 employees. The total number of all employees surveyed was 15, achieving the $100 \%$ response rate: three employees from the sales department, two from the accounting department, and ten lorry drivers. Interviewees were selected according to the survey findings. We selected five participants, who we thought could contribute the most valuable and credible explanations among the office workers and lorry drivers. The criterion purposive sample for the interview (Suri 2011, 6-7) consisted of two office workers from the sales department and three among the lorry drivers. We selected those respondents who we thought could most credibly explain and provide insight related to survey findings.

The survey questionnaire comprises two sets of questions. The first set covers 36 items, divided into nine groups of four, aim- 
ing at assessing the presence or absence of the nine facets of job satisfaction (pay, promotion, supervision, fringe benefits, contingent rewards, operating conditions, co-workers, nature of work, and communication). The response scale in the survey ranges from 1 (strongly disagree) to 6 (strongly agree), whereby only one answer per item is allowed. The second set of survey questions consists of eight items on demographic variables - gender, age, education level, payment, operating position, nationality, and number of years working for the company.

Before conducting the analysis, the negatively worded items were reverse-scored. Each item's score can range from 1 to 6 , the individual facet score can range from 4 to 24 . This is because each facet has four items; the lowest score is the sum of four ones and the highest is the sum of four sixes. A sum total score between 4 and 12 indicates dissatisfaction, a total score between 16 and 24 indicates satisfaction and a total score between 12 and 16 indicates indifference. The total score can range from 36 to 216, with results between 36 and 108 indicating general dissatisfaction, results between 144 and 216 indicating overall satisfaction, and results between 108 and 144 indicating general indifference (Spector 1997, 10).

The data analysis was also conducted in two phases. First statistical analysis of survey data was carried out using the spss (descriptive statistics and indicative use of ANOva), followed by a qualitative content analysis (Bengtsson 2016; Krippendorff 2004) of the semi-structured interview data aiming to explain the detected differences of average satisfaction levels across different work satisfaction facets. The interviews answers were recorded and transcribed (see table 1).

Work in the company is organised in three areas, namely, the sales and truck dispatcher department, the accounting department and the department of (professional) lorry drivers. Therefore, the research builds on the assumption that unequal perceptions of employees' satisfaction are primarily held in the division of labour. Differences were mainly expected between office workers who carry out more pleasant and physically less demanding work, and employees at the operational level (lorry drivers) who are subject to different work conditions.

\section{Results and Findings}

The majority of employees are males (13 employees, 86.7 per cent), in the middle age group from 31 to 40 years (8 employees, 53.3 per cent) and have completed the secondary level of education (7 em- 
TABLE 1 Interview Questions

1 What do you think are the reasons that employees with a lower income are indifferent to benefits, and that benefits cause satisfaction to the employees with higher incomes?

2 How do you explain that employees with a lower income have assessed communication significantly worse than employees with higher incomes? Why do you think such distinction is taking place?

3 How would you explain that drivers are somewhat more indifferent to rewards than employees in offices? In what way do the drivers perceive the relevance of the rewards?

4 Why do you think supervision of the drivers' work is perceived more negatively than office workers, who are somewhat more satisfied with supervision? Where do you see the reason for such a response?

5 How do you explain that a group of employees with lower education is experiencing work supervision more critically, compared to a group of employees with higher education? Determine the way how employees are being supervised.

6 How would you explain the reward system and the fact that employees with higher education are far more satisfied with the rewards than their colleagues with lower education? To what do you attribute this?

7 How do you comment on the finding that employees with higher education in your company are also more satisfied (in the workplace)? How do you think the company can raise the satisfaction of lower-educated employees?

8 Why, in your opinion, in answering the questions, were the employees quite undecided about payment, benefits, rewards, working conditions and communications? Why, in your opinion, they did not opt for extreme satisfaction or dissatisfaction?

9 What makes you think that employees very much appreciated the nature of the work, the co-workers and supervision of the work? What are the factors that cause their satisfaction?

10 What is the reason behind employees being indifferent to promotion? In your opinion, could there be changes in the promotion system?

ployees, 46.7 per cent). Most employees have worked for the company for less than five years (8 employees, 53.3 per cent), under an open-ended employment contract (10 employees, 66.7 per cent) receiving an average gross monthly payment of up to EUR 1.000,00 (8 employees, 53.3 per cent). Most employees are foreigners (8 employees, 53.3 per cent), predominantly engaged as lorry drivers (10 employees, 66.7 percent), and have lower levels of education. The remaining 33.3 per cent of employees are office workers (5 employees), with slightly higher education levels. 33.3 per cent ( 5 employees) of all employees have completed primary and vocational education, 46.7 per cent (7 employees) secondary education and only 20.0 per cent ( 3 employees) have finished higher or university ed- 
ucation. Half of all lorry drivers ( 5 employees, 50.0 per cent) have completed primary or vocational education, and the rest ( 5 employees, 50.o per cent) have completed secondary education. The demographic composition of employees is the result of the recruitment of larger numbers of foreign, less-educated employees for the position of professional driver.

Of all job satisfaction facets, satisfaction with supervision (1) was ranked the highest. Employees assessed supervision with satisfaction. The average index value of $17.3(\mathrm{SD}=4.4)$ showed that respondents are satisfied with the orders and instructions from management, and that they believe their superiors are competent and fair. Another highly ranked facet with an overall average index value of 16.8 ( $\mathrm{SD}=4.3)$ is satisfaction with the nature of work (2), showing that employees see their work as enjoyable, meaningful and they like to perform it. The last highly ranked facet is satisfaction with co-workers (3). The analysis showed an average index value of 16.0 $(\mathrm{SD}=4.5)$, indicating moderate satisfaction with cooperation, mutual trust, and good working relationships.

When assessing the satisfaction with fringe benefits, communication, payment, and contingent rewards, we identified the presence of indifference. Employees' satisfaction with fringe benefits (4) was evaluated with indifference and reached an average value of 15.1 $(\mathrm{SD}=4.5)$, indicating less satisfaction with the distribution of benefits and the existence of rewards and benefits intended for employees. Employees' satisfaction with communication (5) was rated with an average value of $13.4(\mathrm{SD}=5.7)$. The results show slight satisfaction with communication and awareness about what is going on within the organisation as well as with knowledge about the company's goals. Satisfaction with payment (6) received was rated with an average index value of 13.3 (SD = 5.7). Employees expressed slight satisfaction with payments, which also included the adequacy of payments, the feeling of appreciation for a job well done, and the perceived potential for a salary increase. Satisfaction with rules, instructions and working conditions (7) was evaluated with an average value of $13.0(\mathrm{SD}=6.1)$. The respondents believe that some rules and instructions make it difficult to do a job well, mostly because of the many obligations and abundant paperwork. The last facet classified within the range of indifference is satisfaction with contingent rewards $(8)$, with an average value of $13.1(\mathrm{SD}=4.6)$. This shows that employees are believed to carry out work that is respected, as well as to receive certain rewards for efforts. However, they also believe that praise and rewards are not granted often enough. 
TABLE 2 Job Satisfaction Facet

\begin{tabular}{lrr}
\hline Variable & $(1)$ & $(2)$ \\
\hline Payment & 13.3 & 5.7 \\
Promotion & 11.5 & 4.4 \\
Supervision & 17.3 & 4.4 \\
Fringe benefits & 15.1 & 4.5 \\
Contingent rewards & 13.1 & 4.6 \\
Rules, instructions, and working conditions & 13.0 & 6.1 \\
Co-workers & 16.0 & 4.5 \\
Nature of work & 16.8 & 4.3 \\
Communication & 13.4 & 5.7 \\
\hline
\end{tabular}

Notes Column headings are as follows: (1) average, (2) standard deviation.

The last and lowest ranking facet is satisfaction with promotion (9) reaching an estimated average value of $11.5(\mathrm{SD}=4.4)$, indicating the presence of dissatisfaction. The results show that employees expressed dissatisfaction with the promotion opportunities. In spite of this, employees see some opportunities for promotion, but they know it is difficult to achieve them.

Next, we explored job satisfaction differences between groups of employees (tables 3, 4, and 5), by using the analysis of variance results as an indicator of relevant group differences. In the same manner as with the Crosstabs tool, we also explored the indication of possible relationships between the demographic variables and job satisfaction by observing differences in three areas - the amount of payment, achieved levels of education, and employment position.

Depending on the amount of payment, we find significant differences between two groups of employees. According to the company's payment policy, the cut point dividing line between the two groups runs at EUR 1.000,00. The majority of employees (9 employees, 60.0 per cent) reach a payment of up to EUR 1.000,00, followed by the rest of employees (6 employees, 40.0 per cent) that reaches over EUR 1.000,00. A comparison of employees with lower incomes with those with higher incomes reveals that those employees who receive lower incomes were more dissatisfied with communication $(M=10.6)$ in the company compared to employees with a higher income who were more satisfied $(\mathrm{M}=17.5)$.

According to the employment position, there was an evident difference in satisfaction with supervision between the group of lorry drivers and employees performing office work. Lorry drivers expressed indifference $(\mathrm{M}=15.4)$ to supervision, while employees who 
TABLE 3 Group Differences: Payment

\begin{tabular}{|c|c|c|c|c|}
\hline Item & Payment & (1) & $(2)$ & (3) \\
\hline \multirow[t]{3}{*}{ Payment satisfaction } & Up to $€ 1.000,00$ & 9 & 11.6 & 6.6 \\
\hline & Over $€ 1.000,00$ & 6 & 15.8 & 2.9 \\
\hline & Total & 15 & 13.3 & $5 \cdot 7$ \\
\hline \multirow[t]{3}{*}{ Promotion } & Up to $€ 1.000,00$ & 9 & 10.2 & 4.6 \\
\hline & Over $€ 1.000,00$ & 6 & 13.5 & 3.5 \\
\hline & Total & 15 & 11.5 & 4.4 \\
\hline \multirow[t]{3}{*}{ Supervision } & Up to $€ 1.000,00$ & 9 & 16.7 & $5 \cdot 3$ \\
\hline & Over $€ 1.000,00$ & 6 & 18.2 & 2.9 \\
\hline & Total & 15 & 17.3 & 4.4 \\
\hline \multirow[t]{3}{*}{ Fringe benefits } & Up to $€ 1.000,00$ & 9 & 14.2 & $5 \cdot 3$ \\
\hline & Over $1.000,00 €$ & 6 & 16.5 & 2.7 \\
\hline & Total & 15 & 15.1 & 4.5 \\
\hline \multirow[t]{3}{*}{ Co-workers } & Up to $€ 1.000,00$ & 9 & $15 \cdot 3$ & 4.9 \\
\hline & Over $€ 1.000,00$ & 6 & 17.0 & 3.8 \\
\hline & Total & 15 & 16.0 & 4.5 \\
\hline \multirow[t]{3}{*}{ Nature of work } & Up to $€ 1.000,00$ & 9 & 16.1 & 4.9 \\
\hline & Over $€ 1.000,00$ & 6 & 17.8 & $3 \cdot 4$ \\
\hline & Total & 15 & 16.8 & $4 \cdot 3$ \\
\hline \multirow[t]{3}{*}{ Contingent rewards } & Up to $€ 1.000,00$ & 9 & 11.9 & 5.1 \\
\hline & Over $€ 1.000,00$ & 6 & 15.0 & 3.1 \\
\hline & Total & 15 & 13.1 & 4.6 \\
\hline \multirow[t]{3}{*}{ Comunication } & Up to $€ 1.000,00$ & 9 & 10.7 & 5.4 \\
\hline & Over $€ 1.000,00$ & 6 & 17.5 & $3 \cdot 4$ \\
\hline & Total & 15 & 13.4 & $5 \cdot 7$ \\
\hline \multirow{3}{*}{$\begin{array}{l}\text { Rules, instructions and } \\
\text { working condition }\end{array}$} & Up to $€ 1.000,00$ & 9 & 12.7 & 6.3 \\
\hline & Over $€ 1.000,00$ & 6 & 13.5 & 6.4 \\
\hline & Total & 15 & 13.0 & 6.1 \\
\hline \multirow{3}{*}{$\begin{array}{l}\text { Common individual } \\
\text { satisfaction }\end{array}$} & Up to $€ 1.000,00$ & 9 & 119.3 & 42.0 \\
\hline & Over $€ 1.000,00$ & 6 & 144.8 & $23 \cdot 3$ \\
\hline & Total & 15 & 129.5 & 37.0 \\
\hline
\end{tabular}

Notes Column headings are as follows: (1) $N$, (2) mean, (3) standard deviation.

perform office work expressed satisfaction $(\mathrm{M}=21.0)$. Further, significant difference also exists between the employment position and satisfaction with contingent rewards. Here we found that lorry drivers expressed dissatisfaction $(\mathrm{M}=11.5)$, while employees performing office work expressed satisfaction $(\mathrm{M}=16.4)$.

Considering the achieved level of education, differences can be observed in the area of satisfaction with supervision. Those employ- 
TABLE 4 Group Differences: Employment Position

\begin{tabular}{|c|c|c|c|c|}
\hline Item & Employment position & (1) & (2) & (3) \\
\hline \multirow{3}{*}{ Payment satisfaction } & Others & 5 & 16.6 & 5.8 \\
\hline & Lorry drivers & 10 & 11.6 & 5.1 \\
\hline & Total & 15 & 13.3 & $5 \cdot 7$ \\
\hline \multirow[t]{3}{*}{ Promotion } & Others & 5 & 11.8 & 5.4 \\
\hline & Lorry drivers & 10 & 11.4 & 4.1 \\
\hline & Total & 15 & 11.5 & 4.4 \\
\hline \multirow[t]{3}{*}{ Supervision } & Others & 5 & 21.0 & 3.7 \\
\hline & Lorry drivers & 10 & $15 \cdot 4$ & $3 \cdot 5$ \\
\hline & Total & 15 & $17 \cdot 3$ & $4 \cdot 4$ \\
\hline \multirow[t]{3}{*}{ Fringe benefits } & Ostali & 5 & 16.0 & 5.6 \\
\hline & Lorry drivers & 10 & $14 \cdot 7$ & 4.1 \\
\hline & Total & 15 & 15.1 & 4.5 \\
\hline \multirow[t]{3}{*}{ Co-workers } & Others & 5 & 17.4 & 4.6 \\
\hline & Lorry drivers & 10 & $15 \cdot 3$ & $4 \cdot 5$ \\
\hline & Total & 15 & 16.0 & 4.5 \\
\hline \multirow[t]{3}{*}{ Nature of work } & Others & 5 & 19.0 & 4.0 \\
\hline & Lorry drivers & 10 & $15 \cdot 7$ & 4.2 \\
\hline & Total & 15 & 16.8 & $4 \cdot 3$ \\
\hline \multirow[t]{3}{*}{ Contingent rewards } & Others & 5 & 16.4 & 5.1 \\
\hline & Lorry drivers & 10 & 11.5 & $3 \cdot 4$ \\
\hline & Total & 15 & 13.1 & 4.6 \\
\hline \multirow[t]{3}{*}{ Comunication } & Others & 5 & 14.8 & 5.2 \\
\hline & Lorry drivers & 10 & 12.7 & 6.1 \\
\hline & Total & 15 & $13 \cdot 4$ & 5.7 \\
\hline \multirow{3}{*}{$\begin{array}{l}\text { Rules, instructions and } \\
\text { working condition }\end{array}$} & Others & 5 & 13.2 & 8.0 \\
\hline & Lorry drivers & 10 & 12.9 & $5 \cdot 4$ \\
\hline & Total & 15 & 13.0 & 6.1 \\
\hline \multirow{3}{*}{$\begin{array}{l}\text { Common individual } \\
\text { satisfaction }\end{array}$} & Others & 5 & 146.2 & 40.2 \\
\hline & Lorry drivers & 10 & 121.2 & $34 \cdot 3$ \\
\hline & Total & 15 & 129.5 & 37.0 \\
\hline
\end{tabular}

NотеS Column headings are as follows: (1) $N$, (2) mean, (3) standard deviation.

ees who have completed higher education $(\mathrm{M}=23.0)$ are more satisfied with supervision than employees with lower education levels $(\mathrm{M}=13.8)$. In addition, one can observe the existence of differences related to common individual satisfaction, whereby taking into consideration the total (dis)satisfaction index we found that employees with a higher education are more satisfied than employees with a lower education. 
TABLE 5 Group Differences: Payment Satisfaction

\begin{tabular}{|c|c|c|c|c|}
\hline Item & Payment satisfaction & (1) & (2) & (3) \\
\hline \multirow[t]{4}{*}{ Payment satisfaction } & Primary and vocational education & 5 & 10.6 & $4 \cdot 3$ \\
\hline & Secondary education & 7 & 12.7 & 5.8 \\
\hline & Higher and university degree ed. & 3 & 19.0 & 4.6 \\
\hline & Total & 15 & $13 \cdot 3$ & $5 \cdot 7$ \\
\hline \multirow[t]{4}{*}{ Promotion } & Primary and vocational education & 5 & 9.6 & 2.9 \\
\hline & Secondary education & 7 & 11.9 & $5 \cdot 1$ \\
\hline & Higher and university degree ed. & 3 & 14.0 & $4 \cdot 4$ \\
\hline & Total & 15 & 11.5 & $4 \cdot 4$ \\
\hline \multirow[t]{4}{*}{ Supervision } & Primary and vocational education & 5 & 13.8 & 3.0 \\
\hline & Secondary education & 7 & $17 \cdot 3$ & $3 \cdot 4$ \\
\hline & Higher and university degree ed. & 3 & 23.0 & 1.7 \\
\hline & Total & 15 & $17 \cdot 3$ & $4 \cdot 4$ \\
\hline \multirow[t]{4}{*}{ Fringe benefits } & Primary and vocational education & 5 & 12.2 & 3.8 \\
\hline & Secondary education & 7 & $15 \cdot 9$ & 4.1 \\
\hline & Higher and university degree ed. & 3 & 18.3 & $4 \cdot 7$ \\
\hline & Total & 15 & 15.1 & $4 \cdot 5$ \\
\hline \multirow[t]{4}{*}{ Co-workers } & Primary and vocational education & 5 & 13.6 & 3.0 \\
\hline & Secondary education & 7 & $15 \cdot 9$ & 4.8 \\
\hline & Higher and university degree ed. & 3 & 20.3 & 3.1 \\
\hline & Total & 15 & 16.0 & 4.5 \\
\hline \multirow[t]{4}{*}{ Nature of work } & Primary and vocational education & 5 & 14.2 & $4 \cdot 4$ \\
\hline & Secondary education & 7 & 16.7 & 3.6 \\
\hline & Higher and university degree ed. & 3 & 21.3 & 2.3 \\
\hline & Total & 15 & 16.8 & $4 \cdot 3$ \\
\hline \multirow[t]{4}{*}{ Contingent rewards } & Primary and vocational education & 5 & 10.6 & 3.8 \\
\hline & Secondary education & 7 & 12.7 & 4.2 \\
\hline & Higher and university degree ed. & 3 & 18.3 & 2.9 \\
\hline & Total & 15 & 13.1 & 4.6 \\
\hline
\end{tabular}

Continued on the next page

In the case of detecting the interactions between the demographic variables - education, employment position and amount of payment through contingent tables, out of all the pairs' associations emerged only between education and type of work. This tells us that there was a significant association between the variables. We can therefore conclude that the level of education is related to the employment position. Employees with lower education perform mainly the work of professional lorry drivers, while those with higher education occupy mainly more office work positions. 
TABLE 5 Continued from the previous page

\begin{tabular}{llrrr}
\hline Item & Payment satisfaction & (1) & (2) & (3) \\
\hline Comunication & Primary and vocational education & 5 & 10.4 & 5.3 \\
& Secondary education & 7 & 14.3 & 6.0 \\
& Higher and university degree ed. & 3 & 16.3 & 4.9 \\
& Total & 15 & 13.4 & 5.7 \\
\hline Rules, instructions and & Primary and vocational education & 5 & 9.4 & 4.1 \\
working condition & Secondary education & 7 & 13.4 & 6.3 \\
& Higher and university degree ed. & 3 & 18.0 & 6.2 \\
& Total & 15 & 13.0 & 6.1 \\
\hline Common individual & Primary and vocational education & 5 & 104.4 & 29.2 \\
satisfaction & Secondary education & 7 & 130.7 & 33.7 \\
& Higher and university degree ed. & 3 & 168.7 & 24.2 \\
& Total & 15 & 129.5 & 37.0 \\
\hline
\end{tabular}

Notes Column headings are as follows: (1) $N$, (2) mean, (3) standard deviation.

In order to obtain the in-depth explanations of survey findings, semi-structured interviews with the employees were conducted. In particular, we wanted to obtain an insight into the reasons and conditions related to observed differences in job satisfaction and evaluated as dissatisfactory.

First, we wanted to explain the relationship between education and (total individual) employee satisfaction. According to the interviewees, we found that job satisfaction is mainly conditioned by the specific aspects of jobs. Total individual job satisfaction was rated lower by less educated employees, primarily due to working hours and working conditions, which represent the workplace characteristics, in this case, of the job of lorry drivers. As one of the interviewees told us: 'Employees with higher education work in the office, in a warm place. While those with a lower education work in the warehouse, on trucks, in cold and severe conditions[...]' This also confirmed the finding that attained education relates to the occupied job position. The workplace characteristics affect how employees perceive and feel about their job and what causes the experience of job (dis)satisfaction. Complementary explanation is provided by Bakan, Büyükbeşe, and Erşahan (2011, 231-233) as well as Ghafoor $(2012,34)$ who believe that overall job satisfaction is not simply about feelings related to the workplace, but is also subject to commitment, loyalty, experience, and employee expectations due to a higher level of education.

Next, we explored why lorry drivers are more indifferent to con- 
tingent rewards and on what basis they perceive the suitability of contingent reward. Employees believe that the company could easily set up a better rewarding system, since they believe that they are not praised and rewarded enough, according to the survey results. We can arrive at the conclusion that employees want a better rewarding system, which would include a higher wage premium. In particularly for lorry drivers, money is powerful motivator. As one of the interviewees says: 'Drivers perceive rewards, only when they are in the form of money.' For lorry drivers, money is more appreciated than material rewards because it allows them to support themselves and their families, who are located in their home countries (Southeast Europe) and are often quite large. They are also motivated by money since they come from countries with relatively high levels of poverty. In addition, we must be aware of the lifestyle of lorry drivers, who are constantly abroad, which increases living costs. That is one possible explanation for why lorry drivers believe the most appropriate contingent reward for them is to receive money as part of their regular monthly payment. Apart from this, lorry drivers believe that their work is challenging and they should receive better payment or reward. Therefore, it is important, according to Harris $(2001,18-$ 20) and Fischer $(2004,487)$, to establish an appropriate contingent reward system geared to motivate employees and simultaneously strengthen their commitment and loyalty. This may only be achieved if the appropriate reward is given at the appropriate time for specific work, effort or an outstanding achievement.

We also examined why employees with a lower income are indifferent to the fringe benefits provided by the company and why they are less satisfied with the communication. We have already explained how payment relates to satisfaction. These lower scores with fringe benefits can be also attributed to different personal interests and abilities. Employees feel it is particularly important how they can create their own conditions suitable for living with the available monthly payment. Only then and according to their expectations, is it possible to highlight the question of the benefits they receive and enjoy, which is also conditioned by the way of perceiving the fringe benefits. As we know, fringe benefits can increase the feeling of belonging and safety, if employees perceive them as beneficial. Although not entirely satisfied with the fringe benefits provided, the employees still believe they are entitled to them, as well as recognising the related differences among different groups. As one of the interviewees says: 'Different groups carry out different work, which is also appraised differently.' Less-educated employees occupy less at- 
tractive jobs, which are also paid less considering the work complexity. Higher-educated employees work in a friendlier work environment, which is also accompanied by different kinds of remuneration (different long-term employment contracts, prospects of bonuses, daily subsistence allowances etc.). Therefore we can conclude that the fringe benefits received are linked to the different employee's abilities and employment position.

In addition, we identified why employees with a lower income are less satisfied with communication. Employees with a lower income represent a group of lorry drivers who are foreign workers. This group is increasingly facing communication problems generated by the members' insufficient knowledge of Slovenian and other foreign languages. 'Bureaucratic matters also cause us trouble, due to the poor language skills. We often do not understand the background of some things, events [...]' says one of the interviewees. This problem often causes instructions and information to be misunderstood, leading to work mistakes.

The proper functioning of supervision and how it is conducted, as well as different ways of delegating commands and instructions, may evidently also affect employees' feelings. Employees positively evaluate instructions and they consider their superiors to have sufficient competences in these field. At the same time, employees believe that supervision is equitable, because it is not annoying and does not interfere with their privacy. Nevertheless, with further research we found opposing opinions between lorry drivers and office workers. In this respect we wanted to find out why lorry drivers perceived the supervision of their work more negatively and why less-educated workers did not take sides regarding satisfaction with supervision compared to the higher educated employees. Different jobs vary in complexity or responsibility, which in turn requires different levels of supervision. We also found that negative feelings concerning supervision were related to the nature of the work. As one of the interviewees says: 'People with lower education levels mainly occupy the position of lorry drivers who are exposed to increased supervision (tracking via satellite navigation) due to the nature of their work and the value of the cargo.'

The interview responses also provided additional explanations as to why certain aspects of work are perceived with satisfaction, while others are perceived with dissatisfaction or indifference. For those facets characterised by indifference (pay, fringe benefits, contingent rewards, operating procedures and communication), employees say that this is due to the unstable economic situation in the country, 
which impacts the company's operation, employment conditions and the functioning of other companies. Rapid changes in the economic field, legislation and the pressure of competitors, all affect companies' operations, because of different legal restrictions and high operating costs. This consequently affects the payment and rewarding policy, working process as well the interaction and communication in the company. In addition, employees also highlighted the presence of jealousy that occurs among employees, especially when they perceive better conditions and benefits of their co-workers.

The facets of the nature of work, co-workers and supervision were perceived with satisfaction because employees believe that they enjoy good working relationships, which make their work easier to carry out, there are no major conflicts and they solve the problems as they arise. Additionally, the supervision is not annoying, but gives support to employees, by providing information and guidelines. Above all, employees consider that 'it is very important that we have a well-organised working environment, good working conditions and regular payment' says one of the interviewees. This shows that the more intensely employees feel the beneficial effect of work, the greater their satisfaction and the better the results.

As the last evaluated facet, employees express dissatisfaction with career promotion opportunities. Employees in the selected company are facing major restrictions when it comes to promotion opportunities, mainly because of the size of the company. The company is a small family business without a large number of available job positions and accordingly limited career development prospects. Promotion opportunities can act as a strong motivational factor and be perceived as a form of reward because it can change the status of individuals in both their private life and professional field. For companies that cannot provide promotion opportunities it is important to use different strategies to gain new skills and knowledge, as well to enable personal growth and employee development.

\section{Discussion}

The transportation and logistics sector is an important part of the Slovenian economy due to the rising demand for the movement of goods and services, as well as general economic development. The conducted research shows that in the transport and logistics sector the biggest challenge lies in lorry drivers' exposure to the high risk of stressful and exhausting situations that affect their well-being (De Croon et al. 2002, 357; Križman 2008, 15). For this reason, lorry drivers should receive more attention from their top management 
because, after all, they are performing a fundamental work function enabling logistic and transport companies' business performance and survival. The research in the selected transportation and logistics company reveals that employees were satisfied with their supervision, co-workers, and the nature of their work. Indifference was expressed about payment, rewards, benefits, operating procedures, and communication. Dissatisfaction was only identified with the opportunities for career promotion.

A company's performance depends to a large extent upon employees' work performance. However, companies also need to introduce appropriate ways to manage the performance and ways of rewarding and motivating the employees. Since the obtained research results revealed indifferences within the contingent reward among employees, we suggest the adoption of additional performance criteria and standards for individuals and/or groups within the existing performance management system: extent and quality of collaboration, help provided, number of customer complaints, acquisition of new customers etc. The required data could be obtained through written assessments and/or short work reports. Rewarding can also be made dependent upon the involvement and participation of employees in company performance. Therefore, the management should consider the employees' improvement suggestions and make sure to promote the responsibility and diversity of work, in turn affecting the employees' commitment and loyalty. It is also important that companies focus on building a partnership with their employees. Establishing tighter bonds between management and employees helps shape the desired behaviour of employees.

Employees in the transportation and logistics sector are usually paid according to the time spent at the workplace. An appropriate and fair payment can act as a reward, encouraging employees to adopt a specific and particularly desired mode of behaviour important for successful company operations. Given income deviations between employees, it is also important for companies to establish an equitable payment system which observes compensation system design principles (Fisher, Schoenfeldt, and Shaw 2006, 485-512) so that individuals know they have earned the reward through their good work performance. Our suggestion to top management focuses on providing a variety of benefits serving as goal achievement incentives tied to quality criteria like the number of mistakes, working time flexibility, place of work, employee dedication, self-sacrifice, the quality of customers or co-workers relationships, innovation, competence, responsibilities, the nature of work, the amount of work 
performed, the required skills, experience as well as mental and physical efforts. In addition to individual performance, companies can monitor and reward employees based on collective performance.

The effectiveness of transportation and logistics business processes requires a sufficient and quality exchange of information between the employees and the management. Employees play a significant role in this process. We believe that successful communication influences the commitment and participation of employees in the work process and the employees' autonomy. At the same time, it positively affects the relationships and trust among the employees and management. The growing trend of employing foreign workers in road transportation in Slovenia exposes lorry drivers to several problems, such as mutual incomprehension or misunderstanding. Based on the obtained results and the lower assessment of satisfaction with communication (given by the lorry drivers), we propose that top management frequently repeats working instructions and verifies if employees have understood them, while limiting the variety and size of messages or instructions to those employees who have already encountered communication difficulties. Employees' knowledge about handling the necessary transport documentation and working processes should also be frequently refreshed to ensure appropriate knowledge of their work assignments and work performance expectations. We also point out the value of providing a comprehensive explanation when delegating work tasks and for understanding the importance of certain tasks. Due to the use of different technologies, it is also necessary to periodically renew the skills and knowledge related to required technologies.

The fulfilment of career ambitions within transportation and logistics companies can be quite limited given the organisational structure of the companies themselves. Smaller (family-owned) companies face even greater challenges in this respect. Career advancement (promotion) can have a motivational effect on employees when they perceive it as a reward. The results we obtained indicate that employees are not satisfied with the promotional opportunities. Logistics and transportation companies might in that respect consider defining some measures to alleviate or compensate the promotion ambitions if promotion is difficult to obtain. The introduction of training sessions, workshops or training courses for confirming already acquired knowledge might already serve this purpose and at the same time serve the development of human capital which can enhance the company's competitive advantage. The responsibility and autonomy of employees can be achieved by eliminating the work 
monotony by applying job enrichment, and by adding and enriching working tasks. We also see some additional solutions in promoting and educating employees about a healthy life: healthy eating, physical activity and avoiding bad habits that can affect the lorry drivers' physical and mental health (vision, reflexes, concentration etc.). This is largely required for work performed under great pressure and stress, as well as the ergonomic workplace design of lorry drivers (noise, vibration, posture etc.). Among other things, we also emphasise the importance of managerial support for knowledge transfer within working groups. Employees holding specific knowledge and skills should be stimulated by their superiors to share and pass them on to those employees who need it. This in turn allows the expansion of knowledge and consolidation of skills and at the same time gives a sense of appreciation to those employees who share their knowledge with others.

Maintaining the quality, professionalism and efficiency of individuals' work performance requires supervision, which can also backfire if not implemented properly. Our research found that the employees were on average fairly satisfied with the supervision, but a detailed analysis uncovered that the lorry drivers were much more critical. Jakomin and Veselko $(2004,119)$ claim that a driver's work is strongly related to that of a dispatcher in the sales department that manages the composition of the logistics channels and control of goods by considering and adapting to the market conditions, as well as political and weather conditions and other events. It is thus important that the team of dispatchers works well and has the appropriate knowledge and skills required for the good coordination of the lorry drivers' work. Supervision is also linked to the instructions given by dispatchers and to avoiding non-compliance with instructions. It is thus important that lorry drivers understand the valuable role of supervision. That is why we recommend ensuring that the supervision is objective, stimulating and understandable, especially for the lorry drivers.

\section{Conclusion}

The purpose of the research was to present the importance of job satisfaction in the transportation and logistics sector and to provide some solutions and recommendations from the perspective of modern human management. Proposals are based on the acquisition of knowledge, learning, mutual relations and development of both employees and enterprises. We have found that the factors studied can all act as motivational stimuli for employees. With their proper use, 
management can overcome the desired behaviour from its employees, thus building goals in the long run and pursuing the vision of the company.

The research focused on a single company, which brings certain limitations. However, since we are aware that Slovenia has always been considered a transit country, and because the transportation and logistics sector includes a large number of Slovenian companies employing a large number of people, it would make sense to extend the study to a bigger sample of companies and expand the research. Following the research results, we believe that further research is essential, primarily to ensure the safety, industry development and performance of logistic and transportation companies. We see positive implications mainly in the field of improving the quality of work and working conditions of professional lorry drivers, increasing the safety of road users and improving the performance and competitiveness of logistics and transportation companies in the industry.

\section{References}

Anderson, E. W., C. Fornell, and D. R. Lehmann. 1994. 'Customer Satisfaction, Market Share, and Profitability: Findings from Sweden.' The Journal of Marketing 58 (3): 53-66.

Antonaki, X. E., and P. Trivellas. 2014. 'Psychological Contract Breach and Organizational Commitment in the Greek Banking Sector: The Mediation Effect of Job Satisfaction.' Procedia: Social and Behavioral Sciences 148:354-61.

Atefi, N., K. Lim Abdullah, L. P. Wong, and R. Mazlom. 2015. 'Factors Influencing Job Satisfaction among Registered Nurses: A Questionnaire Survey in Mashhad, Iran.' Journal of Nursing Management 23 (4): 448-58.

Babalola, S. S. 2016. 'The Effect of Leadership Style, Job Satisfaction and Employee-Supervisor Relationship on Job Performance and Organizational Commitment.' Journal of Applied Business Research 32 (3): $935-46$.

Bakan, İ., T. Büyükbeşe, and B. Erşahan. 2011. 'An Investigation of Organizational Commitment and Education Level Among Employees.' International Journal of Emerging Science 1 (3): 231-45.

Bener, A., T. Lajunen, T. Özkan, E. Yildirim, and K. S. Jadaan. 2017. 'The Impact of Aggressive Behaviour, Sleeping, and Fatigue on Road Traffic Crashes as Comparison between Minibus/Van/Pick-up and Commercial Taxi Drivers.' Journal of Traffic and Transportation Engineering 5:21-31.

Bengtsson, M. 2016. 'How to Plan and Perform a Qualitative Study Using Content Analysis.' NursingPlus Open 2:8-14.

Blickle, G., J. A. Meurs, A. Wihler, C. Ewen, A. Plies, and S. Günther. 
2013. 'The Interactive Effects of Conscientiousness, Openness to Experience, and Political Skill on Job Performance in Complex Jobs: The Importance of Context.' Journal of Organizational Behavior 34 (8): 1145-64.

Bobnar, A. 2014. 'Spreminjanje zadovoljstva policistov s svojim delom: pregled raziskav od 1993 do 2009.' Doctoral dissertation, University of Maribor, Maribor.

Bovenzi, M., F. Rui, C. Negro, F. D’Agostin, G. Angotzi, S. Bianchi, L. Bramanti, G. L. Festa, S. Gatti, I. Pinto, L. Rondina, and N. Stacchini, 2006. 'An Epidemiological Study of Low Back Pain in Professional Drivers.' Journal of Sound and Vibration 298 (3): 514-39.

Cooper, C. L., and E. A. Locke. 2000. Industrial and Organizational Psychology: Linking Theory with Practice. Oxford: Blackwell.

De Croon, E. M., R. W. B. Blonk, B. C. H. De Zwart, M. H. W. FringsDresen, and J. P. J. Broersen. 2002. 'Job Stress, Fatigue, and Job Dissatisfaction in Dutch Lorry Drivers: Towards an Occupation Specific Model of Job Demands and Control.' Occupational and Environmental Medicine 59 (6): 356-61.

Dimec, T., J. Mahnič, M. Marinšek, R. Masten, and M. Tušak. 2008. 'Zadovoljstvo z življenjem in delovno zadovoljstvo zaposlenih $\mathrm{V}$ Slovenski vojski.' Psihološka obzorja 17 (4): 117-30.

Dubey, R., and A. Gunasekaran. 2015. 'The Role of Truck Driver on Sustainable Transportation and Logistics.' Industrial and Commercial Training 47 (3): 127-34.

Faragher, E. B., M. Cass, and C. L. Cooper. 2005. 'The Relationship between Job Satisfaction and Health: A Meta-Analysis.' Occupational and Environmental Medicine 62 (2): 105-12.

Fischer, R. 2004. 'Rewarding Employee Loyalty: An Organizational Justice Approach.' International Journal of Organizational Behavior 8(3): 486-503.

Fisher, C. D., L. F. Schoenfeldt, and J. B. Shaw. 2006. Human Resource Management. New York: Houghton Mifflin.

Gil, E. A., S. Llorens, and P. Torrente. 2015. 'Compartiendo afectos positivos en el trabajo: el rol de la similitud en los equipos.' Pensamiento Psicológico 13 (1): 93-103.

Ghafoor, M. M. 2012. 'Role of Demographic Characteristic on Job Satisfaction.' Far East Journal of Psychology and Business 6 (1): 30-45.

Godec, L. C. 2013. 'Vzpostavitev pristopa za obvladovanje stresa v projektno orientiranem podjetju.' Undergraduate thesis, University of Ljubljana, Ljubljana.

Gorenak, M. 2011. 'Analiza zaznavanja dejavnikov zadovoljstva slovenskih turističnih vodnikov in spremljevalcev.' Naše gospodarstvo 57 (1-2): 26-34.

Gravetter, F. J., and L. A. B. Forzano. 2015. Research Methods for the Behavioural Science. Belmont, cA: Nelson Education.

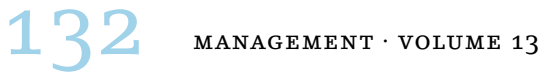


Greenfield, R., E. Busink, C. P. Wong, E. Riboli-Sasco, G. Greenfield, A. Majeed, J. Car, and P. A. Wark. 2016. 'Truck Drivers' Perceptions on Wearable Devices and Health Promotion: A Qualitative Study.' вмс Public Health 16 (1): 677-687.

Gruban, B. 2010. 'Brez motiviranih in zavzetih zaposlenih lahko na uspeh preprosto kar pozabimo.' Ekonomska demokracija 14 (2): 3-6.

Hackman, R. J., and G. R. Oldham. 1974. 'The Job Diagnostic Survey: An Instrument for the Diagnosis of Jobs and the Evaluation of Job Redesign Project.' http://files.eric.ed.gov/fulltext/EDo99580.pdf

Harris, L. 2001. 'Rewarding Employee Performance: Line Managers' Values, Beliefs and Perspectives.' International Journal of Human Resource Management 12 (7): 1182-92.

Harter, J. K., F. L. Schmidt, and T. L. Hayes. 2002. 'Business-Unit-Level Relationship between Employee Satisfaction, Employee Engagement, and Business Outcomes: A Meta-Analysis.' Journal of Applied Psychology 87 (2): 268-79.

Harter, J. K., F. L. Schmidt, and C. L. Keyes. 2002. 'Well-Being in the Workplace and Its Relationship to Business Outcomes: A Review of the Gallup Studies.' In Flourishing: The Positive Person and the Good Life, edited by C. L. Keyes and J. Haidt, 205-24. Washington, DC: American Psychological Association.

Hayes, B., C. Douglas, and A. Bonner. 2015. 'Work Environment, Job Satisfaction, Stress and Burnout among Haemodialysis Nurses.' Journal of Nursing Management 23 (5): 588-98.

Hong, Y., H. Liao, J. Hu, and K. Jiang. 2013. 'Missing Link in the Service Profit Chain: A Meta-Analytic Review of the Antecedents, Consequences, and Moderators of Service Climate.' Journal of Applied Psychology 98 (2): 237-67.

Huang, K. W., J. H. Huang, and G. H. Tzeng. 2016. 'New Hybrid Multiple Attribute Decision-Making Model for Improving Competence Sets: Enhancing a Company's Core Competitiveness.' Sustainability 8 (2): 175-203.

Huczynski, A., and D. A. Buchanan. 2013. Organizational Behaviour. Harlow: Pearson.

Hulin, C. L., and T. A. Judge. 2003. 'Job Attitudes.' In Industrial and Organizational Psychology, edited by I. B. Weiner, 255-71. Handbook of Psychology 12. Hoboken, NJ: Wiley.

Jakomin, I., and G. Veselko. 2004. 'Notranja logistika: načrtovanje, organiziranje in nadzor vseh aktivnosti.' Http://www.gvin.com/einform _guideline_directives_article_news/Default.aspx?Page=Izpis\&ID $=1120$

Jha, S., M. S. Balaji, U. Yavas, and E. Babakus. 2017. 'Effects of Frontline Employee Role Overload on Customer Responses and Sales Performance: Moderator and Mediators.' European Journal of Marketing $51(2): 282-303$. 
Judge, T. A., J. E. Bono, and E. A. Locke. 2000. 'Personality and Job Satisfaction: The Mediating Role of Job Characteristics.' Journal of Applied Psychology 85 (2): 237-49.

Judge, A. T., and L. M. Saari. 2004. 'Employee Attitudes and Job Satisfaction.' Human Resource Management 43 (4): 395-407.

Judge, T. A., C. J. Thoresen, J. E. Bono, and G. K. Patton. 2001. 'The Job Satisfaction-Job Performance Relationship: A Qualitative and Quantitative Review.' Psychological Bulletin 127 (3): 376-407.

Karimi, A., S. Eslamizad, M. Malakoutikhah, M. Mostafaee, and M. Haghshenas. 2017. 'Road Accident Modeling by Fuzzy Logic based on Physical and Mental Health of Drivers.' International Journal of Occupational Hygiene 8 (4): 208-16.

Keenan, K. 1996. Kako motiviramo. Ljubljana: Mladinska knjiga.

Kherbash, O., and M. L. Mocan. 2015. 'A Review of Logistics and Transport Sector as a Factor of Globalization.' Procedia: Economics and Finance 27:42-47.

Korschun, D., C. B. Bhattacharya, and S. D. Swain. 2014. 'Corporate Social Responsibility, Customer Orientation, and the Job Performance of Frontline Employees.' Journal of Marketing 78 (3): 20-37.

Krippendorff, K. 2004. Content Analysis: An Introduction to its Methodology. London: Sage.

Križman, A. 2008. Logistika v gospodarskih družbah: gradivo za 2. letnik. Ljubljana: Zavod IRC.

Levi, E. P. 2006. Industrial/Organizational Psychology: Understanding the Workplace. Boston, MA: Houghton Mifflin.

Lisjak, M. 2011. 'Organizacijska kultura in zadovoljstvo zaposlenih v izbranem podjetju.' In Zbornik 8. Festivala raziskovanja ekonomije in managementa, edited by Š. Bonjec, 309-18. Koper: Fakulteta za management.

Lobe, B. 2006. 'Združevanje kvalitativnih in kvantitativnih metod - stara praksa v novi preobleki?' Družboslovne razprave 22 (53): 55-73.

McElroy, J. C., J. M. Rodriguez, G. C. Griffin, P. C. Morrow, and M. G. Wilson. 1993. 'Career Stage, Time Spent on the Road, and Truckload Driver Attitudes.' Transportation Journal 33 (1): 5-14.

Meneghel, I., L. Borgogni, M. Miraglia, M. Salanova, and I. M. Martínez. 2016. 'From Social Context and Resilience to Performance through Job Satisfaction: A Multilevel Study over Time.' Human Relations 69 (11): 2047-67.

Pavlin, C. 2014. 'Avtoprevozništvo: kako preživeti krizo in hudo konkurenco.' Delo, 24 June. http://www.delo.si/gospodarstvo/posel/ avtoprevoznistvo-kako-preziveti-krizo-in-hudo-konkurenco.html

Pečar, A. 2014. 'Internacionalizacija manjšega slovenskega podjetja v logistični dejavnosti.' Undergraduate thesis, University of Primorska, Koper. 
Peklar, J., and E. Boštjančič. 2014. 'Motivacija in zadovoljstvo z življenjem pri zaposlenih $\mathrm{v}$ javnem in zasebnem sektorju.' International Public Administration Review 10 (3): 36-56.

Peng, J., D. Li, Z. Zhang, Y. Tian, D. Miao, W. Xiao, and J. Zhang. 2016. 'How Can Core Self-Evaluations Influence Job Burnout? The Key Roles of Organizational Commitment and Job Satisfaction.' Journal of Health Psychology 21 (1): 50-59.

Pham, L., and L. Pham. 2016. 'The Effects of Job Satisfaction and Organizational Commitment on Intention to Stay: Case Study at the Universities, Colleges in Bac Lieu City, Bac Lieu Province.' Paper presented at the 1oth International Days of Statistics and Economics, Prague, 8-10 September.

Robbins, S. P., and T. A. Judge. 2015. Organizational Behavior. Harlow: Pearson.

Schermerhorn, J. R., M. Uhl-Bien, R. N. Osborn, and J. G. Hunt. 2012. Organizational Behavior. 12th ed. Hoboken, NJ: Wiley.

Sendall, M. C., P. R. Crane, L. McCosker, H. C. Biggs, M. L. Fleming, and B. D. Rowland. 2016. 'Workplace Interventions to Improve Truck Drivers' Health Knowledge, Behaviours and Self-Reported Outcomes.' Road and Transport Research 25 (1): 31-43.

Söderlund, M. 2017. 'Employee Display of Burnout in the Service Encounter and its Impact on Customer Satisfaction.' Journal of Retailing and Consumer Services 37:168-76.

Skaalvik, E. M., and S. Skaalvik, S. 2017. 'Still Motivated to Teach? A Study of School Context Variables, Stress and Job Satisfaction among Teachers in Senior High School.' Social Psychology of Education 20 (1): 15-37.

Smith, P. C., L. M. Kendall, and C. L. Hulin. 1969. The Measure of Satisfaction in Work and Retirement. Chicago: Rand McNally.

Spector, P. E. 1985. 'Measurement of Human Service Staff Satisfaction: Development of Job Satisfaction Survey.' American Journal of Community Psychology 13 (6): 693-713.

-1997. Job Satisfaction: Application, Assessment, Causes and Consequences. Thousand Oaks, cA: Sage.

Suri, H. 2011. 'Purposeful Sampling in Qualitative Research Synthesis.' Qualitative Research Journal 11 (2): 63-75.

Surugiu, M. R., and C. Surugiu. 2015. 'International Trade, Globalization and Economic Interdependence between European Countries: Implications for Businesses and Marketing Framework.' Procedia: Economics and Finance 32:131-38.

Svetličič, M. 2008. 'Koga in zakaj stiska primež globalizacije?' Družboslovne razprave 24 (58): 7-27.

Špitlar, D. 2009. 'Zadovoljstvo zaposlenih pri delu.' Undergraduate thesis, University of Ljubljana, Ljubljana. 
Vogt, W. P., D. C. Gardner, and L. M. Haeffele. 2012. When to Use What Research Design. New York: Guilford.

Weiss, H. M. 2002. 'Deconstructing Job Satisfaction: Separating Evaluations, Beliefs and Affective Experiences.' Human Resource Management Review 12 (2): 173-94.

Zidar, M. 2009. 'Zadovoljstvo zaposlenih v špedicijskem podjetju.' Undergraduate thesis, University of Primorska, Koper.

Zupan, N. 1999. 'Najboljše prakse ravnanja s človeškimi viri krepijo vlogo zaposlenih v podjetju.' Industrijska demokracija 3 (10): 3-7.

This paper is published under the terms of the Attribution-

NonCommercial-NoDerivatives 4.o International (CC BY-NC-ND 4.0)

License (http://creativecommons.org/licenses/by-nc-nd/4.o/). 